\title{
PRESUPPOSITION AND ITS TRUTH RELATIONS
}

\author{
Diana Sopha \\ Universitas Muslim Nusantara Al-Washliyah \\ Jalan Garu II No.93 Medan \\ dianasopha@.umn.ac.id
}

\begin{abstract}
Abstrak
Penelitian ini berkonsentrasi pada presuposisi yang terdapat di dalam tulisan karya Ernest Hemingway 'Indian Camp'. Selain menemukan presuposisi yang ada di dalam kalimat, penelitian ini juga membahas hubungan kebenaran kalimat dengan presuposisinya. Dengan menggunakan metode deskriptif qualitatif, presuposisi pada kalimat dan hubungan kebenaran antara kalimat dan presuposisi kalimat tersebut diidentifikasi. Jika kalimat tersebut benar atau salah maka presuposisi kalimat akan menjadi benar. Namun sebaliknya jika presuposisi kalimat tersebut benar atau salah maka kalimat tersebut tidak dapat menjadi benar atau salah sehingga kalimat tersebut tidak mempunyai nilai kebenaran.
\end{abstract}

Kata kunci : presuposisi, kalimat, hubungan kebenaran

\begin{abstract}
This research concentrates on the presupposition in Ernest Hemingway's writing 'Indian Camp.' Beside identifying the Presupposition of the sentences, it also analyses the truth relation of the sentence and its presupposition. By using descriptive qualitative method, the presuppositions of the sentences and their truth relations are identified. If the sentence is true or false then the presupposition of the sentence is true. In contrast, if the presupposition of the sentence is true or false, the sentence will neither be true nor false, so it does not have truth value.
\end{abstract}

Keywords : presupposition, sentence, truth relation

\section{INTRODUCTION}

\subsection{Background of the Problems}

Language plays a significant role in human life. All humans use language as their means of communication. Language involves pronunciation, structure, including meaning. Meaning is a very important element in language. The speakers will not be able to use language if they do not understand its meaning. Saeed (2000:3) said the study of meaning communicated through language is called semantics. So semantics is the study of meanings of words and sentences. A person's linguistics abilities are based on knowledge that they have. It is the knowledge we are seeking to investigate. The speakers of a language have different types of linguistic knowledge, including how to pronounce words, how to construct sentences and about the meaning of individual words and sentences. Kearns (2000:1) said that the study of linguistic meaning is generally divided in practice into main fields, semantics and pragmatics. Semantics deals with the literal meaning of words and the meaning of the way they are combined, which taken together from the core of meaning or starting point from which the whole meaning of a particular utterance is constructed.

One of discussions in meaning is presupposition. Leech (1981:281) defines presuppositions is what is publicly interpretable not with intentions or assumptions of the speaker such as I don't know when you stop lying to her. The speaker of this sentence presupposes that you lie to her more than one time and it is 
not necessary to say that the speaker of this sentence believes in what he or she presupposes. So presupposition is assumed as the way that a person uses or interprets a sentence in a certain situation and it depends on someone's ability to understand the sense of the sentence. One sentence may have more than one presupposition. For example My friend is a major's son. This sentence has two presuppositions. The first presupposition is I have a friend and the second one is The major has a son.

There is a truth relation between the sentence and its presupposition. Katz (1981:281) said the truth of presupposition of a sentence must follow from the truth of the sentence but if the presupposition of the sentence is false then the sentence has no truth value, i.e. will be neither true or false. If the sentence is false, its presupposition must be true. For instance the sentence My brother is sick has presupposition I have a brother. If $M y$ brother is sick is true then I have a brother is true. If My brother is sick is false then I have a brother is still true. If I have a brother is true or false then My brother is sick will neither be true nor false or does not have truth value.

\subsection{Problems of the Research}

This research has two problems to answer. They are:

a. What are the presupposition of sentences in Ernest Hemingway's writing?

b. How is the truth relation of the sentence and its presupposition?

\subsection{Objectives of the Research}

The objectives of the Research are to identify:

a. The presupposition of the sentences in Ernest Hemingway's writing

b. The Truth relation of the sentence and its presupposition

\section{METHOD}

This research uses a qualitative method since the data are in qualitative terms. The research of Presupposition Analysis in Ernest Hemingway's Writing is using descriptive-qualitative approach. This research is qualitative since it gives explicit specific explanation of collecting data and analysis procedure (Hartoyo,2010:27). Bogden and Biklen (1992:106) said that data are the raw materials that a researcher collects from the basis of analysis. The data are taken from Ernest Hemingway's article 'Indian Camp'. The sequences of obtaining the data are chronologically elaborated as follows:

a. Reading the writing as the data of the research

b. Identifying the presupposition of the writing

c. Analyzing the truth relation of the sentence and its presupposition

d. Elaborating the result of the analysis

e. Drawing conclusions

\section{DISCUSSION}

As previously mentioned that Presupposition is the interpretation of a sentence in a certain situation by someone with his/her ability to understand the sentence meaning. This research discusses the meaning of sentences expressed in Ernest Hemingway's writing. Through the research, it can be found the presupposition of the sentences and there is also truth relation between the sentence and its presupposition. The sentences are analyzed as follows:

- At the lake shore, there was another rowboat drown on presupposes there was the lake shore. There was lake shore is true whether the sentence At the lake shore, there was another rowboat drown on is true or false but if There was lake shore is true or false the sentence At the lake shore, there was another rowboat drown on is neither true nor false or does not have truth value. 
- The two Indian stood waiting presupposes there were Indians. The presupposition there were Indians is true no matter the sentence. The two Indian stood waiting is true or false, but if the presupposition there were Indians is true or false the sentence The two Indian stood waiting will be neither true nor false.

- Uncle George sat in the stern of the camp rowboat presupposes there was Uncle George. The presupposition there was Uncle George is true whether the sentence Uncle George sat in the stern of the camp rowboat is false but if the presupposition there was Uncle George is true or false the sentence Uncle George sat in the stern of the camp rowboat will be neither true nor false.

- The Indians rowed with quick choppy strokes presupposes there were Indians. The presupposition there were Indians is true even if the sentence The Indians rowed with quick choppy strokes is true or false. While if there were Indians is true or false the sentence The Indians rowed with quick choppy strokes will be neither true nor false.

- Nick lay back with his father's arm around him presupposes Nick had a father. The presupposition Nick had a father is true if the sentence Nick lay back with his father's arm around him is true or false. Whereas if Nick had a father is true or false the sentence Nick lay back with his father's arm around him will be neither true nor false.

- Uncle George was smoking a cigar in the dark presupposes uncle George was a smoker. The presupposition uncle George was a smoker is true if the sentence Uncle George was smoking a cigar in the dark is true or false but if the presupposition uncle George was a smoker is true or false the sentence Uncle George was smoking a cigar in the dark will be neither true nor false.

- More dogs rushed out at them presupposes there were dogs. The presupposition is true. The presupposition there were dogs is true if the sentence More dogs rushed out at them is true or false but if the presupposition there were $\operatorname{dog} s$ is true or false the sentence More dogs rushed out at them will be neither true nor false.

- An old woman stood in the doorway holding a lamp presupposes there was an old woman. The presupposition there was an old woman is true if the sentence An old woman stood in the doorway holding a lamp is true or false but if the presupposition there was an old woman is true or false the sentence An old woman stood in the doorway holding a lamp will be neither true nor false.

- All the old women in the camp had been trying to help her presupposes all the old women were in the camp. The presupposition all the old women were in the camp is true if the sentence All the old women in the camp had been trying to help her is true or false but if the presupposition all the old women were in the camp is true or false the sentence All the old women in the camp had been trying to help her will be neither true nor false.

- In the upper bunk was her husband presupposes she had a husband. The presupposition she had a husband is true if the sentence In the upper bunk was her husband is true or false but if the presupposition she had a husband is true or false the sentence In the upper bunk was her husband will be neither true nor false.

- The room smelled very bad presupposes there was a room. The presupposition there was a room is true if the sentence The room smelled very bad is true or false but if the presupposition there was a room is true or false, the sentence The room smelled very bad will be neither true nor false.

- The husband in the upper bunk rolled over against the wall presupposes the husband was in the upper bunk. The 
presupposition the husband was in the upper bunk is true if the sentence The husband in the upper bunk rolled over against the wall is true or false but if the presupposition the husband was in the upper bunk is true or false the sentence The husband in the upper bunk rolled over against the wall will be neither true nor false.

- Nick held the basin for his father presupposes Nick had a father. The presupposition Nick had a father is true if the sentence Nick held the basin for his father is true or false but if the presupposition Nick had a father is true or false the sentence Nick held the basin for his father will be neither true nor false.

- His curiosity had been gone for a long time presupposes he had a curiosity. The presupposition he had a curiosity is true if the sentence His curiosity had been gone for a long time is true or false but if the presupposition he had a curiosity is true or false the sentence His curiosity had been gone for a long time will be neither true nor false.

Uncle George looked at his arm presupposes there was Uncle George. The presupposition there was Uncle George is true if the sentence Uncle George looked at his arm is true or false but if the presupposition there was Uncle George is true or false the sentence Uncle George looked at his arm will be neither true nor false.

- The Indian lay with his face toward the wall presupposes there was Indian. The presupposition there was Indian is true if the sentence The Indian lay with his face toward the wall is true or false but if the presupposition there was Indian is true or false the sentence The Indian lay with his face toward the wall will be neither true nor false.

- A bass jumped making a circle in the water presupposes there was a bass. The presupposition there was a bass is true if the sentence A bass jumped making a circle in the water is true or false but if the presupposition there was $a$ bass is true or false the sentence $A$ bass jumped making a circle in the water will be neither true nor false.

- The sun was coming up over the hills presupposes there was a sun. The presupposition there was a sun is true if the sentence The sun was coming up over the hills is true or false but if the presupposition there was a sun is true or false the sentence The sun was coming up over the hills will be neither true nor false.

- Nick trailed his hand in the water presupposes there was Nick. The presupposition there was Nick is true if the sentence Nick trailed his hand in the water is true or false but if the presupposition there was Nick is true or false the sentence Nick trailed his hand in the water will be neither true nor false.

- It felt warm in the sharp chill of the morning presupposes the morning was sharp chill. The presupposition the morning was sharp chill is true if the sentence It felt warm in the sharp chill of the morning is true or false but if the presupposition the morning was sharp chill is true or false the sentence It felt warm in the sharp chill of the morning will be neither true nor false.

\section{CONCLUSIONS}

Based on the discussion of the research, there are two conclusions. First, the presuppositions are found in the sentences of Ernest Hemingway's writing. Secondly, there is a truth relation of presupposition and its sentence. A presupposition influences sentence truth and the truth of the presupposition is free from the falsity of the sentence. If the sentence is true or false, the presupposition is still true while the truth or falsity of the sentence is influenced by the truth of presupposition. If the presupposition is true or false the sentence will not be true nor false because if it is false so the sentence will never be uttered and if the 
presupposition is true the sentence cannot be true or false too because it does not give enough interpretation for the sentence to be true or false.

\section{REFERENCE}

Bogdan, RC and Biklen, S.K.(1992). Qualitative Research for Education: An Introduction to Theory and Methods. The United State of America: Allyn and Bacon.

Hartoyo. (2010). Research in Education (Compilation). Fakultas Bahasa dan Seni-Universitas Negeri Semarang.

Katz,J.J. (1981). Semantic Theory. New York : Harper and Row Publisher.

Kearns, Kate.(2000). Semantics.New York : Saint Martin's Press.

Leech, Geoffrey. (1981). Semantics (The Study of Meaning). Harmondworth : Penguin

Saeed,John.I. (2000). Semantics.Blackwell Publisher ltd. 